\title{
An Insight on Archbishop Desmond Tutu's Struggle Against Apartheid in South Africa
}

\author{
Alexander Kokobili \\ The Evangelical Theological Faculty, Charles University in Prague, Czech Republic \\ alexkokobili@yahoo.com
}

UDK: 329.42

Review paper

https://doi.org/10.32862/k.13.1.5

\section{Abstract}

This article focuses of Archbishop Desmond Tutu's role against the apartheid system of racism and socio-political inequality in the Republic of South Africa. Tutu often denounced apartheid in his speeches and public advocacy promoting equality, reconciliation, and peaceful coexistence of all South Africans. The ideology of apartheid robbed the black race in South Africa of their human dignity which contradicts the Holy Bible which states, "So God created man in His own image; in the image of God He created him; male and female He created them" (Genesis 1:27). Despite this, the white National Party of South Africa in 1948 legitimized apartheid as a political system and gained support from the Dutch Reformed Church despite its anti-Christian ethics. Apartheid was adopted to place the white minority in the upper class, while the black majority was left with fewer rights and fewer privileges in South Africa. Desmond Tutu was one of the few Christian leaders in Africa who championed the course for black theology in the demolition of apartheid in South Africa. Tutu's attitude during the apartheid struggle was not by violent protest or riots but rather through his sermons and public participation in activities clamoring for national unity, love, and equality of all South Africans.

Keywords: apartheid, human rights, equality, racial inequality and oppression, reconciliation. 


\section{Introduction}

Emeritus Archbishop Desmond Tutu (b. 1931, South Africa) became a prominent figure against the apartheid racial segregation in of South Africa from 19821995. Tutu, an Anglican bishop, was appointed as secretary general of South African Council of Churches in 1978 and later received the Nobel Prize for Peace in 1984. He spoke against the apartheid political system of racial segregation and condemned the white-dominated Dutch Reformed Church for supporting the inhuman policies of the ruling Africaaner government. The system of apartheid was introduced in 1948 by the nationalist party of South Africa as part of its political structure to racially divide the people of South Africans into Black, Colored, and White (SAHO 2000). This political pattern favoured the white Afrikaans with more privileges in social, religious, and political rights. Through this action, the South African ruling minority government supported racism, preferential land ownership, tribal segregation in access to public utilities and political offices, restrictions on interracial marriages of black and white South Africans. Tuto believed in human equality and advocated against the black marginalization in their own country by the white minority. He explained, "when you discover that apartheid sought to mislead people into believing that what gave value to human beings was a biological irrelevance, really, skin color, or ethnicity, and you saw how the scriptures say it is because we are created in the image of God, that each one of us is a God-carrier. No matter what our physical circumstances may be, no matter how awful, no matter how deprived you could be, it doesn't take away from you this intrinsic worth" (Tutu 1982, 46). The period of apartheid in South Africa coincided with white minority rule in countries like Namibia, Zimbabwe, Malawi, Botswana, etc., and colonialism in other parts of Africa by the British, French, Belgian, and Portuguese from the 1870s until the 1970s.

\section{Apartheid Not Welcomed!}

Christianity has always been referred to as a religion of love, peace, and reconciliation which was the mission of Jesus Christ. Unfortunately, the apartheid era in South Africa divided South Africans and religiously the Dutch Reformed Church cared less about it due to connection the church had with government. This is because the Church adopted an ideology of "Chosen People" which was misinterpreted from John Calvin's advocacy for elections in the state (Institutes 3.21, 1.1-4). Contrary to Calvin; they saw themselves as part of the white race that was the chosen race of God in superiority to their fellow black South Africans. They aligned themselves as Imperial Calvinist in South Africa and also misinterpreted Calvin's rights of people to be elected to political office. The church believed that 
election to governance was for a Chosen People, as predestined to be the superior human race above another (Institutes 3.21, 1.1-4). This belief was perceived differently for several centuries by the white Afrikaners. For instance, "The Dutch Afrikaner's role as interpreter of the Afrikaner heritage began as early in the 1870s as the Voortrekkers were compared to the Lord's chosen people. Nevertheless, this theme, which had so readily contributed to the development of apartheid (for as a chosen), the Afrikaners, it is argued, justifiably separate themselves from other people and legitimately exercise lordship over them" (Ellingensen 1999, 267). This reason also justified the white Dutch Reformed Church support for the ruling Dutch National party's apartheid racial politics which contravenes human dignity. For instance, Daniel F. Malan, former apartheid prime minister (1948-1954), explained during his tenure, "Our history is the greatest masterpiece of the centuries. We told this nationhood as our due for it was given us by the Architect of the universe. [God's] aim was the formation of a new nation among the nations of the world" (Moodie 1975). Malan's Afrikaner misconception of racial superiority of the white minority was to create a new nation, based on white supremacy as the creation of God over the black majority. Moreover, this also brought European imperialism to chock up Ubuntu culture to the black South African society, by oppressing their cultural values and identity. For Tutu, apartheid created a polarization between the blacks and whites in the South African society in which both races developed hatred and annoyance towards themselves. Hence, there was it was necessary to restore the human dignity and traditional Ubuntu community life that originally established the South African society.

Furthermore, the apartheid system closed up South African politics into racism and aggression against the blacks. The situation deprived the black South Africans of the right to use their land, while the white Afrikaans lavished in abundance as superior human beings. The idea of a closed society promoted gross violations of human rights and racial injustice which is alien to a democratic society. For instance, Karl Popper kicked against such as society because it permits oppression and the oppressed could revolt someday. He explained, "Modern totalitarianism is only an episode with the perennial revolt against freedom and reason. From older episodes it is distinguished not so much by its ideology, as by the fact that its leaders succeeded in realizing one of the boldest dreams of their predecessors; they made the revolt against freedom a popular movement" (Popper 1945, 57). Thus, the apartheid agenda of the Dutch Nationalist Party opposed the freedom and equality of Black South Africans. However, a democratic society should be opened to accommodate all human races as one people created by God. The society must care for the affairs of all citizens regardless of race or status class and government must not marginalize the rights freedom of any group of people. Hence, any political regimes connected to Apartheid such 
as Marxism, Fascism, Nazism, Totalitarianism, Colonialism, etc., must not be allowed to dictate the affairs of the society because of its failure to uphold human dignity and freedom for all.

\section{Tutu's Ethical Virtues on Equality}

Tutu's belief in the Bible propelled his idea on the gospel of equality of all races. He quoted St. Paul saying, "for He is our peace, who hath made both one, and hath broken down the middle wall of partition between us" (Ephesians 2:14). Tutu believed the separation of God's people in South Africa based on race is considered a wall of partition which was already demolished by Christ Jesus. He explained the need to respect human dignity and rights of the black South Africans saying, "the fact that even the church does not practice reconciliation, is more than the unfortunate state of affairs. It is nothing short of a contradiction of the very nature of the church" (Tutu 1982, 18). This shows the hypocrisy of the white Dutch Reformed Church in its claim of reconciliation in South Africa even though it claimed apartheid was in a conflict of the gospel in 1978 synod (1982, 18). Tutu's struggle was also influenced by Martin Luther King Jr., civil rights movement of the 1960s. By 1986, Tutu was awarded the Martin Luther King Jr. "Non-Violent Prize" for the struggle against apartheid. Tutu was also inspired by King's 1963 Birmingham city jail letter of Alabama and in 1982 he became the head of the South African Council of Churches (SACC). However, he maintained the ideology of racial liberation was a collective responsibility of both the church, civil movements, and foreign sympathizers. Tutu believed the redemption of South Africa was God's plan to liberate the country out of the materialist ideology of the ruling white minority and the oppressive style of tyranny. He explained, "It is God's mission and purpose for His world to bring about wholeness, justice, good health, righteousness, peace and harmony, and reconciliation. These are what belong to the kingdom of God, and we are His agents to work with him as partners to bring to pass all that God wants us to His universe" (Tutu 1982, 26). That is, the aim of the church is to ensure the existence of the love of God in the society always because it serves as God's vessel to bring positive change to society. The church must not be neutral to the injustice of apartheid but must speak against the socio-political injustice and the marginalization of God's people.

Tutu's theology was influenced by his strong moral biblical conviction on human equality in the Holy Bible (Galatians 3:28, "There is neither Jew nor Greek, there is neither bond nor free, there is neither male nor female: for ye are all one in Christ Jesus"). To him, the white Afrikaans must realize the land of South Africa originally belongs to the blacks despite their introduction of Christianity from Europe. Hence, there is a need to reconcile both the Bible and the land for 
a peaceful existence. He explained, "When the white man first came here, he had the Bible and we had the land. Then the white said to us, come let us kneel and pray together. So, we knelt and closed our eyes again, so we had the Bible and he had the land" (Tutu and Battle 2009, 31). The desire for economic dominance by the white Afrikaans resulted in the white minority quenching their godly conscience for racial oppression. The misconception of the white Dutch Reformed Church of South Africa was contrary to Calvin's Reformation of rights and human freedom. Also, the idea of the love of one's neighbour in the Holy Bible had been neglected for the love of power and oppression by the apartheid government and the Dutch Reformed Church. In acknowledgment, the former Afrikaner president, W.A. de Klerk, later vindicated Tutu's theology of human equality by stating, "Justice is no cowardly surrender of one's strivings, rights, and claims. Justice is obedience. Justice is to live according to the rule or law of the creator. To act according to the law for your own life is to express your own character and identity. Your own character is, therefore, your 'law of life' and the obedience to it is justice. Therefore, we say that autogenous development is the best exercise of justice. Justice is a plurality, whoever deserts his own post and endangers his future, who by virtue of a misconception of love or justice, undertakes to fulfill the task of someone else is not exercising justice but is disloyal to his own calling and law of life" (Tutu and Battle 2009, 31). However, the abolition of apartheid with a new constitution of South Africa in 1994 marked the end of an era of gross human rights violations and racial inequality. The post-apartheid era opened the society to civil democracy, while the Dutch Reformed Church and white Afrikaner acknowledged their roles in human rights violations while testifying in the 1995 Truth and Reconciliation Commission. Tutu's idea of human rights was a bridge of hope, in connecting the nations of Africa on the values of racial equality and human rights. Tutu's theology pursued fairness for the black man and justice from all racial violations from the white man through compensation and the appropriate committee for racial reconciliation. His gospel of reconciliation became the beacon of hope amidst the bitterness that was looming in the society and the victims must be ready to forgive the apartheid oppressors. However, the quest for national reconciliation by Tutu and the black churches in South Africa remained united and was supported by the international community, despite the unlawful imprisonment and exiling of black clergies and civil activists.

\section{Tutu's 1982 Trial in the Eloff Commission}

Tutu's persistence against apartheid gave voice and courage to other churches to stand for human freedom and equality in South Africa. As chairman of the South African Council of Churches (SACC) in 1982, Tutu criticized the apartheid legi- 
slation of the Afrikaner government on grounds of racism, religious segregation, and socio-political injustice. He was arranged by the Afrikaner national government on trial before the 1982 Eloff Commission, due to his opposition against the apartheid government. This was because the Afrikaner government considered Tutu and churches who criticized its regimes as rebels and disobedient to civil order. During the trial, Tutu condemned the actions of the ruling Afrikaner national party and the Dutch Reformed church as heretical, evil, and wicked. He explained, "We are under trial for being Christian and that by a Government which claims to be a Christian. It may be that we are being told that it is an offense to be a Christian in South Africa" (Tutu 1982,4,6). The explanation of Tutu to the Eloff government commission described apartheid as evil, anti-god and from sin. However, the Alliance of Reformed Churches in South Africa was not in support of it due to its white dominant Afrikaner members. Also, Tutu applauded the appointment of the non-white clergy (Allan Boesak), as the President of the World Alliance of Reformed Churches in 1982 for supporting Godly values of the church on equality of all races (Tutu 1982, 4-9).

Furthermore, he compared the evil of apartheid to Nazism and Communism in which the vicious system only succeeded in promoting injustice and oppression among the black majority in the country (Tutu 1982, 6). Hence, Tutu warned the government not to tread in the path of the atrocities of Adolf Hitler, Emperor Nero, etc. because governments are ordinary human beings and should not be tyrants (Tutu 1982, 9). He likewise appealed for the freedom of the South African Council of Churches from political maneuverings of the state and that the church must prevail above all forms of evil and injustice with freedom from the tyranny of apartheid in the land (Tutu 1982, 9). Moreover, for Tutu, the resurrection of Jesus Christ over death is the power of the church over the wickedness of apartheid in the society. That is, according to the Bible, "if God is for us, who can be against us" (Romans 8:31) (Tutu 1982, 9). The comparison of apartheid was likened to the evil of Nazism and Communism in which the vicious system only succeeded in promoting injustice and against Black South Africana. To this, Tutu warned the government not to tread in the path of the atrocities of Adolf Hitler, Benito Mussolini, Emperor Nero, Lenin, Stalin, etc. because governments are ordinary human beings and should not be tyrants. (Tutu 1982, 9). He appealed for the freedom of the South African Council of Churches from political maneuverings of the state and that the church must prevail above all forms of evil and injustice with freedom from the tyranny of apartheid in the land (Tutu 1982, 9). Similarly, Tutu spoke against the heretical doctrines of Dutch Reformed church saying they are evil and wicked. He stated, "We are under trial for being Christian and that by a Government which claims to be a Christian. It may be that we are being told that it is an offense to be a Christian in South Africa" (Tutu 1982, 4, 6). That is to 
say, Tutu's explanations during the Eloff government commission criticized the evil and racist regime of apartheid.

\section{Tutu and the 1995 Truth and Reconciliation Commission in South Africa}

Tutu and other civil activists met with Mandela in 1990 after his release from 27 years of apartheid imprisonment to discuss the future of South Africa. Tutu went into the meeting thanking the almighty God in a hymn (Let your will be done, O Lord God of truth) and thereafter prayed for the nation of South Africa (Tutu 1982, 4-6). The meeting gave the nation the idea for what would be Tutu's 1995 commission. Tutu was later appointed by President Mandela as chairman of the 1995 Truth and Reconciliation Commission, which comprised of several stakeholders from the Anglican, Methodist, Roman Catholic Churches, a Muslim, a Hindu, politicians and civil rights groups representing white, colored, and black South Africans (Tutu 1982, 4-6). The pro-apartheid white Dutch Reformed Church was invited to attend the national reconciliation. The focus of Tutu's commission was to create an opportunity for justice for the oppressed and healing for damaged emotions and trust, while at the same time reintegrating the oppressors back to the society of love and humility. Also, Tutu pleaded for amnesty for the white oppressors as a way of making all persecutors accept their wrong deeds for the purpose of peace. This was not seen a sign of weakness for the black race but rather all in the spirit of reconciliation. Tutu encouraged all participants during the commission on the need for forgiveness just as God forgave us all from our trespasses. Tutu explained the need for forgiveness as a mandate of the Truth and Reconciliation Commission stating, "the central concern is not retribution or punishment, but in the spirit of Ubuntu, the healing of breaches, the redressing of imbalances, the restoration of broken relationship" (Tutu 1999). That is, the call for justice was also placed as priority as a way of compensating those who were victims of gross human rights violations such as torture, unlawful imprisonment, rape, murder, etc. This means that the victims and their families should be fully compensated by the government in several ways such as financial settlement, emotional or mental rehabilitation, restoration of seized land and reunification of communities. However, an emphasis on the need for repentance and acknowledgment of wrong behavior and crimes by the white apartheid oppressors was also included in the objective of the commission. Tutu's commission also encouraged all apartheid perpetrators to be remorseful and the tender apologies to their victims as part of the spirit of reconciliation and forgiveness preached by the love of Jesus Christ. 


\section{Tutu's Ubuntu Theology}

Bishop Tutu's formulation of a theological concept of reconciliation was inspired by a local slogan from the popular Zulu South African culture called Ubuntu. Tutu's usage of the Ubuntu focuses on the African concept of community which puts emphasis on the integrity of human beings created to live in the image of God even in the midst of conflict (Tutu and Batle 2009, 5). To this, Tutu encourages the oppressed to see beyond the experiences of the past but forgive the one who oppressed before and embraces such a person as one family of God. This is because the South African society has its traditional Ubuntu lifestyle of love and togetherness of all people regardless of ethnicity. Tutu's Ubuntu theology of reconciliation became an inspiration for embracing forgiveness and healing caused by violations of human rights during the apartheid era. For instance, former president Nelson Mandela in an interview in 2006 explained the relevance of Ubuntu while he was growing up in South Africa. To him, Ubuntu means tolerance, respect, humility, forgiveness, togetherness, respect, trust, sharing, etc. which are the core values of society (Mandela 2006). Tutu's pursuit of oneness in South Africa contradicts the ideology of racial segregation inscribed in the hearts of white South Africans as superior to their black neighbour's. He explained, "apartheid makes no logical sense (because) it denies human beings are created in the image of God; that is to say, this imago Dei theology better determines humanity because racial ideology inevitably leads to the use of power, and the oppressor makes claim to tell you who you are" (Tutu and Battle 2009, 5). The idea of reconciliation between the oppressed and oppressor in a society is based on the principle of community life which existed in South Africa before the oppression of apartheid. Hence, the oppressed people must look beyond revenge and the oppressor must change from his evil deeds and respect the land was given by God for all people to inhabit. However, Tutu's Ubuntu tradition of reconciliation called for a South Africa that looks beyond racial tension to a life of peaceful coexistence. This means, "we can be human only in the community, in koinonia, in peace" (Tutu and Battle 2009, 5). Thus, a major deception of apartheid to the religious life in South Africa was to picture God as the author of racial segregation. For instance, the white Afrikaners described apartheid as a Christian principle based on justice, which would maintain and protect the white race as a distinctive group (Tutu and Battle 2009, 23). To this, Daniel F. Malan former apartheid prime minister (1948-1954) in South Africa justified the Dutch system of racial segregation by the government stating, "Our history is the greatest masterpiece of the centuries. We told this nationhood as our due for it was given us by the Architect of the universe. [God's] aim was the formation of a new nation among the nations of the world" (Tutu and Battle 2009, 23). Malan's Afrikaner misconception of racial 
superiority of the white minority was to create a new nation based on white supremacy as creations of God over the black majority. For Tutu, apartheid created a polarization between the blacks and whites in the South African society in which both races developed hatred and annoyance towards themselves. Moreover, Tutu explained his belief differently from the former apartheid Prime Minister Daniel Malan saying, "apart from the deep hurt that apartheid policy inflicted on all its victims such as assaults on their human dignity; there is an agony of apartheid, the Bantustan policy which means to turn blacks into aliens in their own mother-country, so that there will be no black South Africa" (Tutu and Battle $2009,26)$. The idea of apartheid also oppressed the local culture and togetherness aimed undermining the human dignity of black South Africans. Moreover, the re-awareness of Ubuntu was to restore original community life that established the black society.

For Tutu, the white Afrikaners must realize the land of South Africa originally belongs to the blacks despite their introduction of Christianity from Europe. That is to say, the desire for economic dominance by the white Afrikaans resulted in the white minority quenching their godly conscience for racial oppression. Nevertheless, the black majority now realize that the same Bible received by the whites opened their eyes to the Ten Commandments of God, which focuses on love for oneself and the neighbor. Thus, the idea of love has been neglected for the love of power and oppression by the apartheid government and the white Dutch Reformed Church. However, Tutu called for a type of reconciliation that restores forgiveness and equality for both the black and white as one people created by God to jointly enjoy the prosperity of the land. The invisible wall of apartheid was finally repealed from the legislation of South Africa in 1994 just like the fall of the Berlin wall in 1989. Hence, Tutu's campaign was justified with all South Africans seeking reconciliation and future as a country rather than racial or tribal governmental policies. For instance, former Afrikaner president, W. A. de Klerk, who repealed the racial laws and vindicated Tutu's theology of reconciliation stating, "Justice is, therefore, no cowardly surrender of one's own strivings, rights, and claims. Justice is obedience. Justice is to live according to the rule or law of the creator. To act according to the law for your own life is to express your own character and identity. Your own particular character is, therefore, your 'law of life' and the obedience to it is justice. Therefore we say that autogenous development is the best excuse for justice. Justice is a plurality, whoever deserts his own post and endangers his future, who by virtue of a misconception of love or justice, undertakes to fulfill the task of someone else is not exercising justice but is disloyal to his own calling and law of life" (Tutu and Battle 24). Hence eventually, the white Afrikaners had no choice but to embrace the proposal of reconciliation and accept the blame for their atrocities towards the black majority 
in 1990. At this point, the struggle was not about racial or ethnic supremacy but the need for equality in human rights and freedom. The black South Africans also accepted their land was given to them by God, but now it also belongs to all citizens of the republic including their white neighbours. To Tutu, the Ubuntu theology of reconciliation of South Africa can also be likened to the virtues of Jesus Christ the good shepherd who gave His life for mankind to be reconciled to Him in repentance. He explained, "And Jesus says there is greater joy in heaven over one sinner who repents than over ninety-nine needing no repentance. Christians are constrained by the imperatives of this Gospel, the Good News of a God who had a bias for sinners contrary to the normal standards of the world. What we are, what we have, even our salvation is still a gift, not to be achieved but to be received as a gift freely given. God does not give up on anyone, for God loved us from all eternity, God loves us now and God will always love us, all of us, good or bad, forever and ever. Those who think this opens the door for moral laxity have obviously never been in love, for love is much more demanding than law" (Tutu 1999, 74-75). This is because the Ubuntu ideology of reconciliation places the relevance of humility, peace, and community togetherness against revenge to the apartheid perpetrators.

\section{Summary}

This article gives an insight into Tutu's role in the struggle against apartheid in South Africa and his influence thereafter. Tutu's influence is still relevant in the advocacy for peace, love, and reconciliation in the African continent. For instance, Tutu's role as the president of the All Africa Conference of Churches (AACC) in 1994 bestowed him the opportunity of visiting several African countries with the vision of national reconciliation. Tutu and his team visited mainly countries which had suffered severely from human rights abuses with the aim of helping to restore healing in the land (Tutu 1999, 206-207). This was also significant for a country like Nigeria which suffered from years of military dictatorship and human rights abuses before it became a democratic state in 1999. As a result, the Nigerian government also established a Human Rights Violations Investigation Commission in 1999 and appointed Catholic Bishop Mathew Kukah to serve as its secretary. Other countries such as Liberia and Angola, which suffered years of civil war, formed similar commissions. Tutu's influence also encouraged democratic governance in parts of Africa previously dominated by a military dictatorship.

Furthermore, despite Tutu's advocacy, the delay in the implementation of reports by peace and reconciliation committees in countries such as Sudan, Zimbabwe, and the Central African Republic, etc. has infringed on the 1948 United Nations Human Rights Charter. Also, the church must not relent in its effort in 
preaching God's love as constantly emphasized by Tutu's message on equality and reconciliation. To this, there is a constant appeal for all humans to embrace dialogue in conflict and appreciate the efforts of Christianity in the pursuance of peace. This also earned Tutu an invitation by President Pasteur Bizimungu of Rwandan to speak to the nation after the genocide of the Hutu tribe against the Tutsi's in 1994. Also, Tutu's unending support for peace is still unchanging in this century. He explains, "Peace is possible, especially if today's adversaries were to imagine themselves becoming friends and began acting in ways that will promote such a friendship developing in reality. It would be wonderful if, as they negotiated, they tried to find ways of accommodating each other's needs. A readiness to make concessions is a sign of strength, not weakness" (Tutu 1999, 226). That is, the church must always focus on the positive sides in pursuing peace as the hope of mankind to save the earth from further destruction of God's people. The church should always accept its responsibilities and be part of the reconciliation against discrimination of people in the African continent. Finally, Tutu's laboratory of reconciliation in the society is not a place for social experiment but a message of Jesus Christ giving freedom, love and hope to all citizens on this earth.

\section{Literature}

A history of Apartheid in South Africa. 2016. http://www.sahistory.org.za/article/ history-apartheid-south-africa (acceessed on 19. 11. 2018.)

Calvin, John. 2011. The Institutes of Christian Religion (translated by Henry Beveridge). Seattle, Pacific Publishing Studio.

Dunbar, Moodie, T. 1975. The Rise of Afrikanerdum: Apartheid and the Afrikaner Civil Religion. Regents University of California Press.

Ellingesen, Mark. 1999. Reclaiming our Roots: Martin Luther to Martin Luther King Jr. (Vol 2). Trinity Press.

Mandela, Nelson. Experience ubuntu.ogv. author:@canonical, Ltd. Date: 24 May 2006.

Popper, Karl. 1945. The Open Society and its Enemies. Vol 2 The tide of high prophecy: Hegel, Marx and the Aftermath. London. George Routledge \& Sons LTD.

Tutu, Desmond. 1982. On Trial (1 September 1982 + South Africa + Government puts Council of Churches on trial + Tutu before Eloff Commission).

Tutu Desmond. 1999. No Future without Forgiveness. Random House South Africa (Pty) Limited. 
Tutu Desmond i Michael Battle. 2009. Reconciliation: the Ubuntu theology of Desmond Tutu. Cleveland. The Pilgrim Press.

\author{
Alexander Kokobili
}

\title{
Uvid u borbu nadbiskupa Desmonda Tutua protiv apartheida u Južnoj Africi
}

\begin{abstract}
Sažetak
Ovaj članak razmatra ulogu koju je nadbiskup Desmond Tutu odigrao u borbi protiv rasizma i socio-političke nejednakosti koju je promicao sustav apartheida u Južnoafričkoj Republici. Tutu je često u svojim govorima i javno-zagovaračkim istupima osuđivao apartheid te promicao jednakost, pomirenje i miran suživot svih Južnoafrikanaca. Ideologija apartheida je crncima u Južnoj Africi otuđila svako ljudsko dostojanstvo, što je u suprotnosti sa Svetim Pismom u kojem piše: „Tako Bog stvori čovjeka na sliku svoju. Stvori ga na sliku Božju. Stvori ih kao muža i ženu" (Postanak 1,27). Usprkos tome je 1948. godine bjelačka Nacionalna južnoafrička stranka ozakonila apartheid kao politički sustav i pri tom dobila podršku Nizozemske reformirane crkve unatoč tome što se radilo o primjeni etike koja je protivna kršćanstvu. Apartheid je u Južnoj Africi usvojen s ciljem da se bijela manjina pozicionira kao viša društvena klasa, dok je crnačkoj većini bilo oduzeto niz prava i povlastica. Desmond Tutu bio je jedan od malobrojnih kršćanskih vođa koji je u Africi utirao put crnačke teologije pri rušenju apartheida u Južnoj Africi. Tijekom njegove borbe protiv apartheida, Tutu nije poticao na nasilne prosvjede ili nerede, već je više pokušavao djelovati više kroz svoje propovijedi i poticati javnost na sudjelovanje u aktivnostima koje su promicale nacionalno jedinstvo, ljubav i jednakost svih Južnoafrikanaca.
\end{abstract}

